\title{
Article \\ Catalytic Prebiotic Formation of Glycerol Phosphate Esters and an Estimation of Their Steady State Abundance under Plausible Early Earth Conditions
}

\author{
Maheen Gull * and Matthew A. Pasek (D) \\ School of Geosciences, University of South Florida, 4202 E Fowler Ave., NES 204, Tampa, FL 33620, USA; \\ mpasek@usf.edu \\ * Correspondence: ambermaheen@yahoo.com
}

check for

updates

Citation: Gull, M.; Pasek, M.A. Catalytic Prebiotic Formation of Glycerol Phosphate Esters and an Estimation of Their Steady State Abundance under Plausible Early Earth Conditions. Catalysts 2021, 11, 1384. https://doi.org/10.3390/ catal11111384

Academic Editors: Charles $\mathrm{Xu}$ and Tianliang Lu

Received: 30 October 2021

Accepted: 14 November 2021

Published: 17 November 2021

Publisher's Note: MDPI stays neutral with regard to jurisdictional claims in published maps and institutional affiliations.

Copyright: (c) 2021 by the authors. Licensee MDPI, Basel, Switzerland. This article is an open access article distributed under the terms and conditions of the Creative Commons Attribution (CC BY) license (https:/ / creativecommons.org/licenses/by/ $4.0 /)$.

\begin{abstract}
The emergence of biological phosphate esters of glycerol could have been a crucial step in the origin and evolution of life on the early Earth as glycerol phosphates today play a central role in biochemistry. We investigate here the formation of the glycerol phosphates by employing various rock samples, salts, and minerals as potential catalysts to aid the phosphorylation process. We report the synthesis of various phosphate esters of glycerol including glycerol-1-phosphate, glycerol-2phosphate, cyclic glycerol-monophosphate as well as various diphosphate esters. Furthermore, the decomposition rates of glycerol phosphate under mild heating were also studied while keeping the $\mathrm{pH}$ constant. It was observed that glycerol phosphate starts decomposing quickly under mild heating conditions into inorganic orthophosphate and pyrophosphate, and a steady state concentration of $\sim 0.5 \mathrm{M}$ of glycerol phosphate may have been reasonable in ponds with abundant glycerol, phosphate, urea, and catalytic minerals.
\end{abstract}

Keywords: phosphorus; phosphate esters; esterification; minerals; catalysis; origin of life; glycerol phosphates; phosphorylation; condensation; chemical evolution; decomposition

\section{Introduction}

Glycerol phosphates (GP) play a central role in modern biochemistry. These compounds are directly associated with crucial life processes, such as cellular respiration and cell structure [1]. For a better understanding of the origin and evolution of early membranes, it is essential to understand the prebiotic syntheses of GP, which also are critical to the synthesis of phospholipids, an essential component of cell membranes in almost all organisms [2-4]. GP links via a phosphate diester bond to form a 'head group' that is the polar/hydrophilic part of the phospholipid molecule [4]. The roles of GP in the origin and evolution of cell membranes in various organisms have been discussed previously [4]. In addition, GP and its derivatives also play central roles in several other metabolic pathways such as respiration.

Prebiotic syntheses of GP have been reported previously by using ammonium phosphates to phosphorylate glycerol with condensation agents at $85^{\circ} \mathrm{C}$ [5], under simulated hydrothermal conditions and by using various minerals and clays as catalysts [6], by employing various non-aqueous solvents [7-9], by using high energy phosphates such as amidophosphates [10], and by the formation of activated phosphate, e.g., imidazole phosphate, which then reacts with the organic compounds [11].

In addition, the plausible syntheses of GP from the meteoritic mineral schreibersite $\left(\mathrm{Fe}_{2} \mathrm{NiP}\right.$, or its synthetic analog $\left.\mathrm{Fe}_{3} \mathrm{P}\right)$ have been reported [12]. Recently, another pathway of GP synthesis has also been reported in phosphine-doped interstellar analog ices of methanol $\left(\mathrm{CH}_{3} \mathrm{OH}\right)$, carbon dioxide $\left(\mathrm{CO}_{2}\right)$, or water $\left(\mathrm{H}_{2} \mathrm{O}\right)$ exposed to high energy radiation [13]. Both studies $[12,13]$ highlight extraterrestrial, abiotic pathways leading to the formation of GP.

The above-mentioned methods have challenges such as the use of non-aqueous solvents that may not be prebiotically prominent [7-9], high energy conditions that may degrade 
organic substrates $[5,6,13]$ and use of high energy phosphates, which are uncommon in the rock record [10]. Furthermore, since water was the most realistic solvent on the Hadean earth [14,15], the most plausible prebiotic scenario for formation of GP would utilize water as a solvent, under mild heating conditions and the condensation would possibly be facilitated by the utilization of prebiotically relevant condensation agents such as urea [5,16-18]. Moreover, minerals could have further facilitated the catalysis of the prebiotic synthesis of GP [6]. Minerals such as kaolinite and quartz are prebiotically relevant silicates that have been shown to catalyze various prebiotic reactions $[7,18]$. The significance of silicates has also been discussed previously [19] (also see Tables 2 and 3 of [19]). Hematite has also been used in the prebiotic synthesis of GP [6]. Similarly, borates (including ulexite) have been considered to have played an important role in the chemical origin of biological molecules, particularly in the plausible stability of sugars [20-22], even though their presence on the Hadean Earth is somewhat questionable [23]. Olivines $\left(\left[\mathrm{Fe}, \mathrm{Mg}_{2} \mathrm{SiO}_{4}\right)\right.$ are considered to be one of the most ubiquitous and primitive minerals on the Earth [24-26]. These react with water to produce a rock type known as a serpentinite, and liberates molecular hydrogen $[27,28]$. Iron hydroxides, olivine, serpentinites and volcanic glasses are deemed to be of high prebiotic relevance [26,29] (also see Table 2 of [26]). In addition to the above-mentioned minerals, basaltic rocks were likely ubiquitous and are among the oldest known rocks [30].

In the present study, we attempt to phosphorylate glycerol under mild heating conditions. We have mimicked a prebiotically plausible drying hot pool of water containing a dissolved organic (glycerol), a condensation agent (urea), a phosphate (ammonium phosphate), along with various minerals including kaolinite, quartz, hematite, magnetite, olivine, ulexite, and salts $\left(\mathrm{NH}_{4} \mathrm{Cl}, \mathrm{NaCl}, \mathrm{Na}_{2} \mathrm{CO}_{3}\right)$ and some relevant rock samples (serpentinite, obsidian, and basalt). These substances were investigated for their role in the formation of GP. We also investigated GP decomposition under similar conditions in order to constrain a plausible steady-state concentration of GP on the early earth.

\section{Results and Discussions}

In our model of a drying hot pool containing glycerol, phosphates, urea, and combined with minerals, salts, or rock samples, we observed synthesis of various phosphate esters of glycerol (Table 1 and Figures 1-4, Scheme 1). In addition to the expected phosphate esters, e.g., glycerol-1-phosphate, glycerol-2-phosphate, we also observed cyclic monoglycerol phosphate, and various isomers of glycerol diphosphate (two orthophosphates linked up to a glycerol molecule on different carbons not as a pyrophosphate linkage). The ${ }^{31} \mathrm{P}-\mathrm{NMR}$ yields of the phosphorylated products were calculated based on the peak integration methods as previously reported [7-9,12,18].

Table 1. Yields ${ }^{1}(\%)$ of various phosphates species detected in the phosphorylation of glycerol.

\begin{tabular}{|c|c|c|c|c|c|c|c|c|c|c|}
\hline Sample & Catalyst & $\mathbf{a}$ & $\mathbf{b}$ & c & $\mathrm{d}$ & e & f & $\mathrm{g}$ & $\mathrm{h}$ & Net Org. $\mathrm{PO}_{4}$ \\
\hline 1 & None & 3 & 2 & ND & 95 & ND & ND & ND & ND & 5 \\
\hline 2 & $\mathrm{Na}_{2} \mathrm{CO}_{3}$ & 26 & 21 & ND & 13 & 18 & 8 & 7 & 7 & 80 \\
\hline 3 & Serpentine & 21 & 8.5 & 1 & 33 & 25 & ND & ND & 11.5 & 55.5 \\
\hline 4 & Hematite & 18 & 10 & 1 & 8 & 50 & ND & ND & 13 & 79 \\
\hline 5 & Obsidian & 22 & 14 & 1 & 9 & 42 & 2 & 2 & 8 & 83 \\
\hline 6 & $\mathrm{NaCl}$ & 4 & 3 & ND & 93 & ND & ND & ND & ND & 7 \\
\hline 7 & Basalt & 30 & 5 & 4 & 8 & 40 & 2 & 2 & 9 & 83 \\
\hline 8 & Magnetite & 31 & 7 & 6 & 5 & 42 & 2 & ND & 7 & 88 \\
\hline 9 & $\mathrm{NH}_{4} \mathrm{Cl}$ & 22 & 15 & ND & 20 & 20 & 13 & ND & 10 & 70 \\
\hline 10 & Ulexite & 57 & 17 & 4 & 20 & ND & ND & ND & 2 & 78 \\
\hline 11 & Quartz & 31 & 23 & ND & 12 & 12 & 5 & ND & 17 & 71 \\
\hline 12 & Olivine & 21 & 6 & 5 & 1 & 32 & 14 & 13 & 8 & 91 \\
\hline 13 & Kaolinite & 65 & 15 & 3 & 11 & ND & ND & ND & 6 & 83 \\
\hline
\end{tabular}

${ }^{1}$ The yields of the phosphorylated products as well as other inorganic phosphates were calculated based on the total phosphorus dissolved and by the peak integration method as previously reported [18]. The various compounds are represented as follows; glycerol-1-phosphate (a), glycerol-2-phosphate (b), cyclic GP (c), orthophosphate (d), various isomers of glycerol-diphosphate (e, f, and g) and inorganic P species (h), respectively. ND is "not detected". 


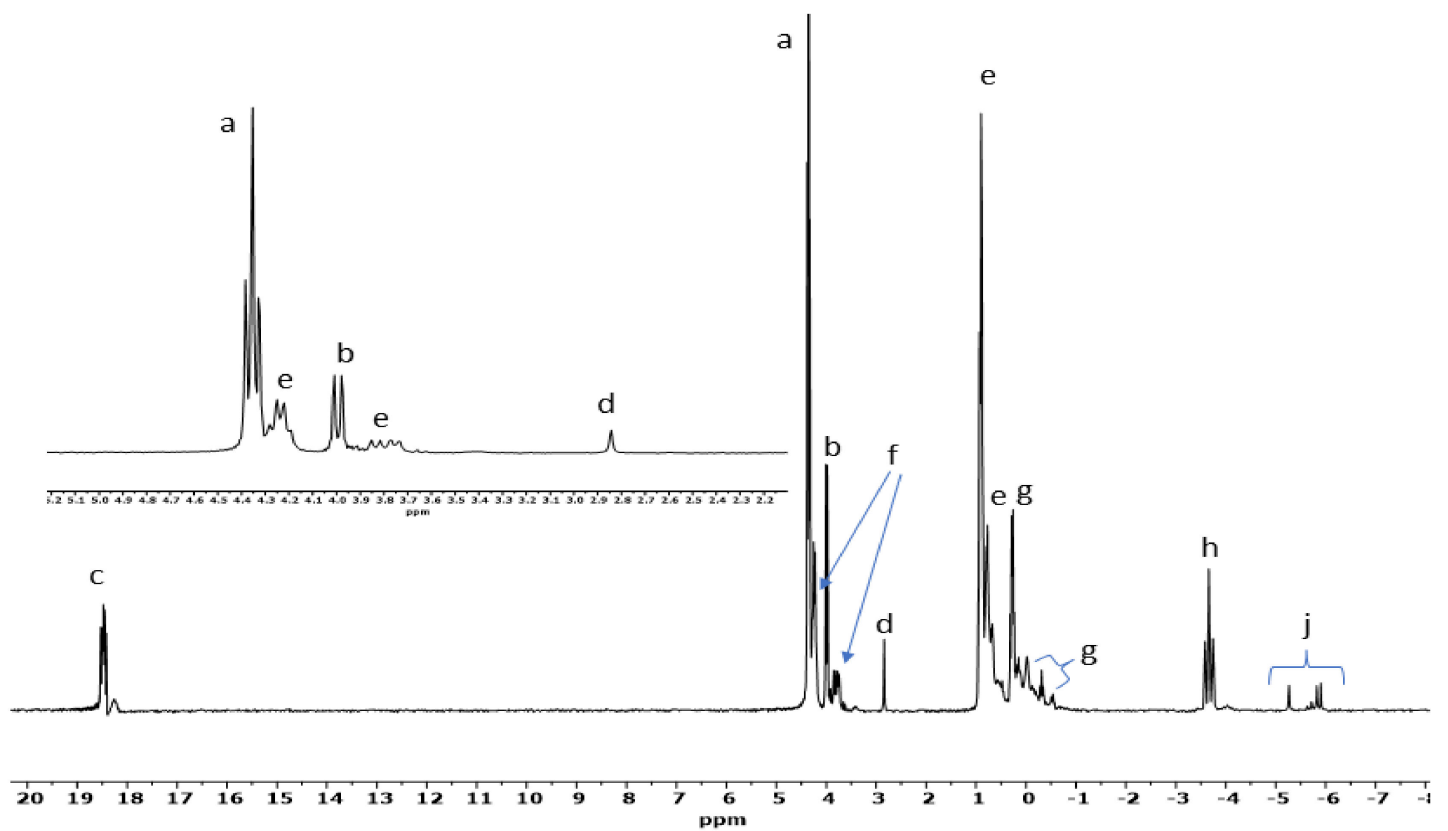

Figure 1. ${ }^{31} \mathrm{P}-\mathrm{NMR}$ of GP formation in the presence of olivine. In addition to all the peaks already discussed. This sample also had some unidentified inorganic phosphate species labeled as peaks ' $h$ ' and ' $j$ '.

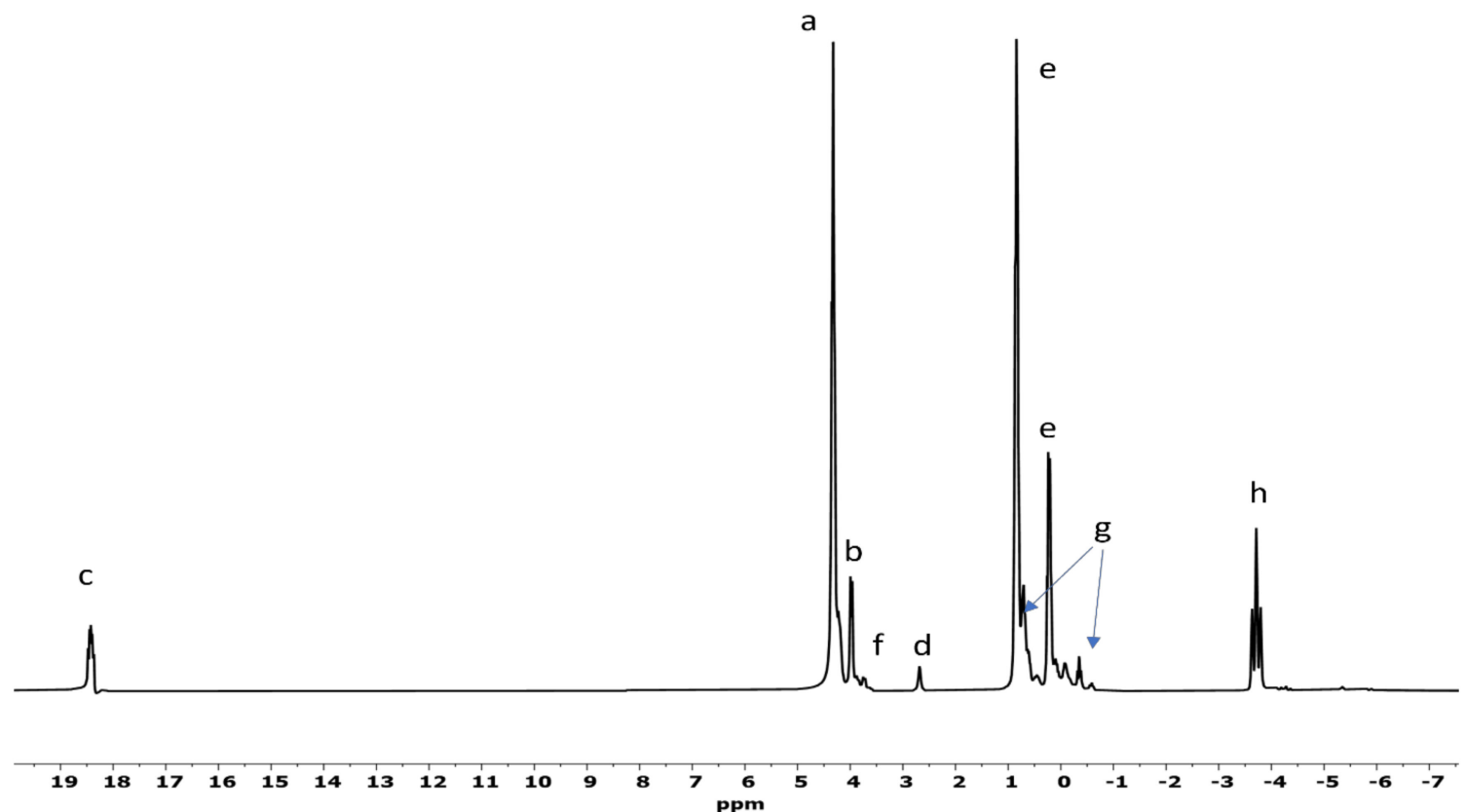

Figure 2. Formation of GP in the presence of basalt. Peak ' $\mathrm{g}$ ' is also a plausible isomer of GP diphosphate. 


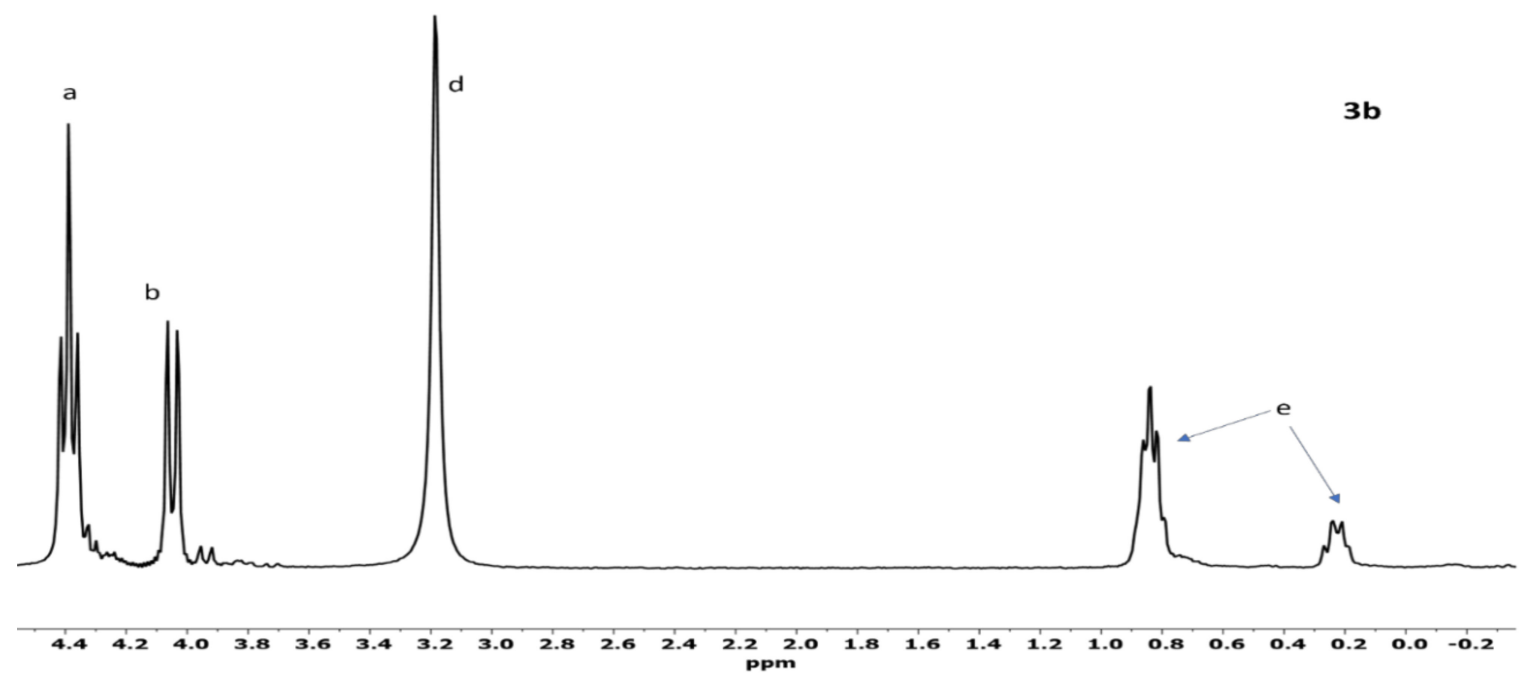

$3 a$

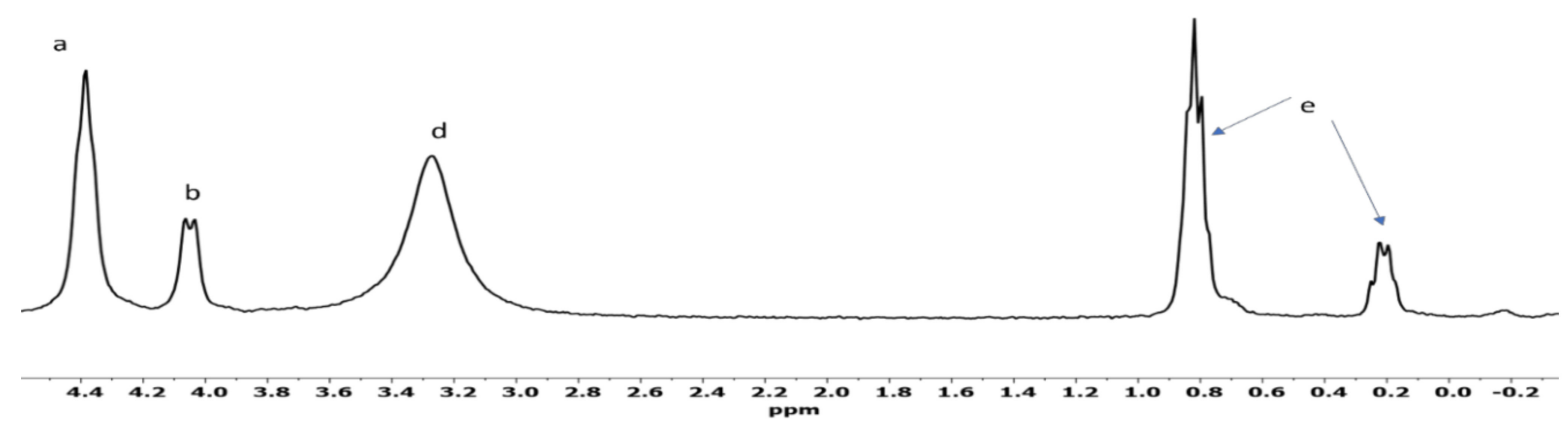

Figure 3. Comparable spectra of GP formation in the presence of serpentine as a catalyst. The unspiked spectrum (a) and same reaction spiked with standard GP $(\mathbf{b})$.

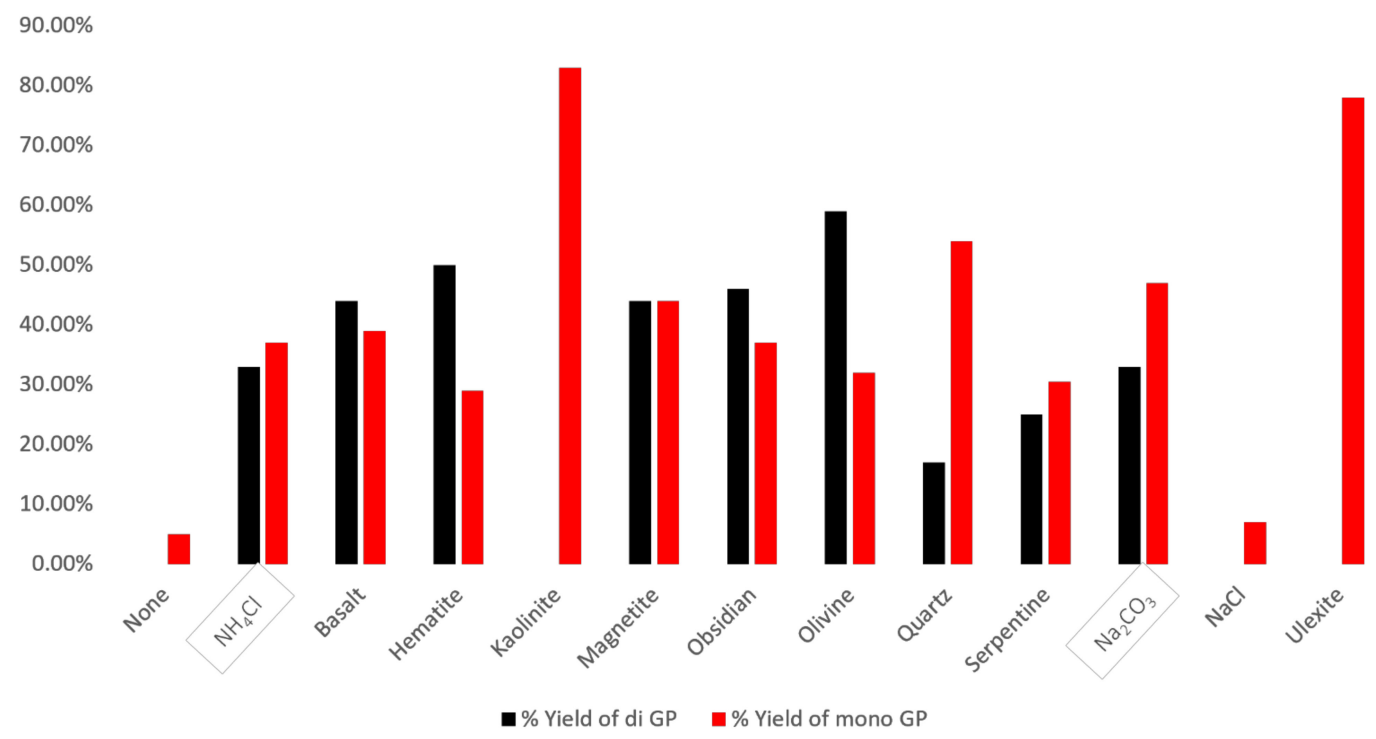

Figure 4. The comparable yields (\%) of mono GP (glycerol-1-phosphate, glycerol-2-phosphate and cyclic mono GP) and di GP in the presence of various catalysts. 


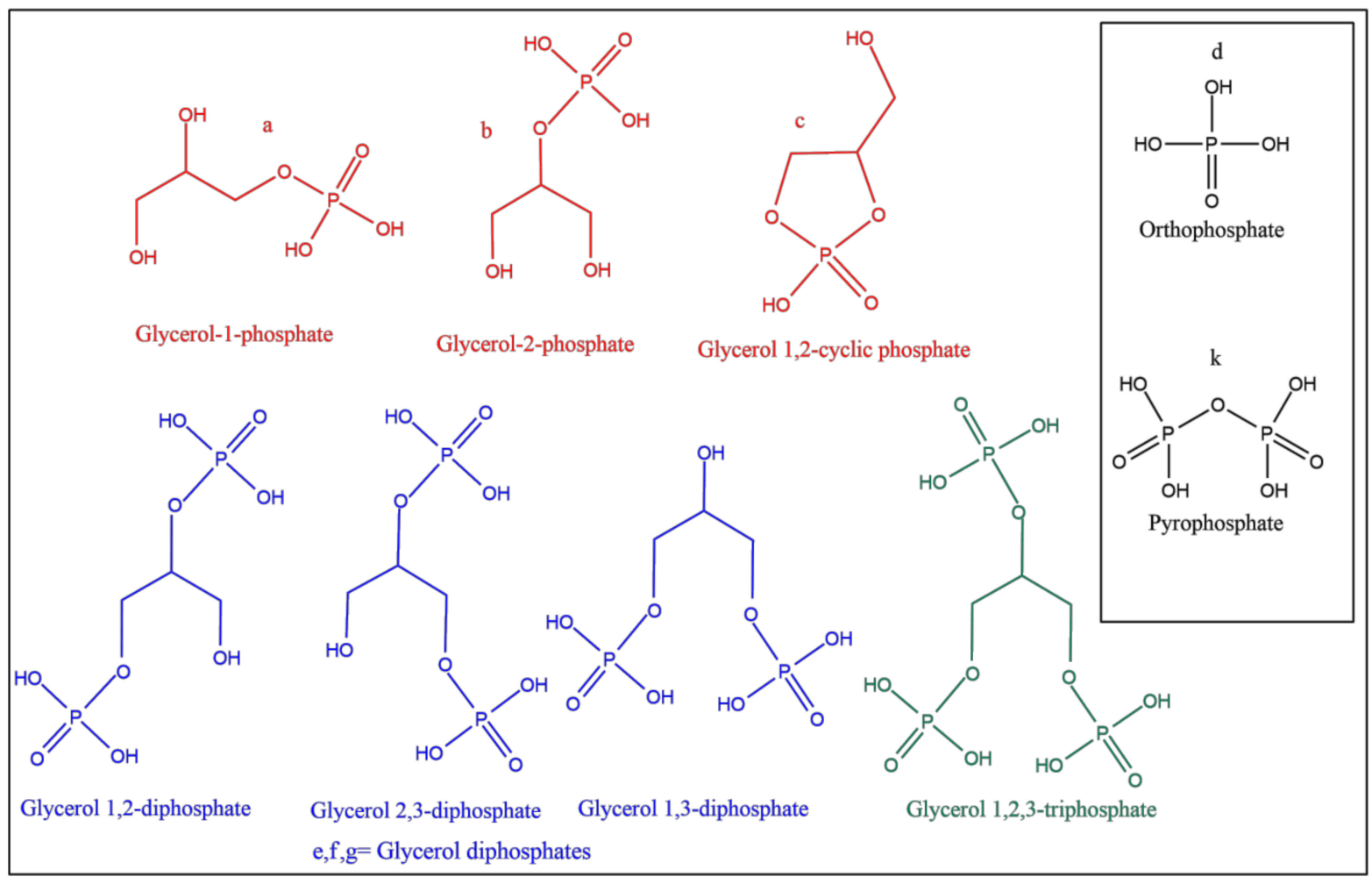

Scheme 1. The structures of various compounds discussed in the text. The labeling of the structures is also similar to that mentioned in the NMR figures and Tables 1 and 2. Glycerol monophosphates (red), inorganic phosphates (black), glycerol diphosphates (blue) and glycerol triphosphates (green), respectively.

Table 2. Yields ${ }^{1}(\%)$ of the decomposition products of GP.

\begin{tabular}{cccccccccc}
\hline Sample & $\mathbf{a}$ & $\mathbf{b}$ & $\mathbf{c}$ & $\mathbf{d}$ & $\mathbf{e}$ & $\mathbf{f}$ & $\mathbf{k}$ & $\mathbf{N e t}$ & Org. $\mathbf{P O}_{\mathbf{4}}$ \\
\hline Set & 1 & 46 & 35 & ND & ND & ND & 19 & ND & 100 \\
Set & 2 & 49.50 & 30 & ND & 3.5 & 0.5 & 14 & 2.5 & 94 \\
Set & 3 & 39 & 19 & ND & 5 & 1 & 17 & 19 & 76 \\
Set & 4 & 28.50 & 12 & ND & 4.7 & 0.8 & 13 & 41 & 54.3 \\
Set & 5 & 46 & 35 & ND & ND & 1 & 18 & ND & 100 \\
Set & 6 & 46 & 32 & ND & 0.5 & 0.5 & 21 & ND & 99.5 \\
Set & 7 & 36 & 20 & ND & 4 & 0.5 & 15.5 & 24 & 72 \\
Set & 8 & 45 & 14 & ND & 7 & 1 & 5 & 28 & 65 \\
\hline
\end{tabular}

${ }^{1}$ As mentioned in the description of Table 1 , the yields of the decomposition products as well as other inorganic phosphates were calculated based on the total phosphorus dissolved and by the peak integration method as previously reported [18]. In the Table 2, various compounds are represented as follows; glycerol-1-phosphate (a), glycerol-2-phosphate (b), cyclic GP (c), inorganic orthophosphate (d), various isomers of glycerol-diphosphate (e and f), and inorganic pyrophosphate (k). ND means "not detected".

In a typical reaction, heating glycerol with ammonium phosphate, urea, and with the added catalyst (mineral, salt, and rock sample), the overall yield of the GP was remarkably improved. No phosphorylated products were observed without urea. When the reaction was carried out in the presence of urea but in the absence of the catalysts, phosphorylation was observed but the yields were relatively very low (Table 1). Various phosphorylated derivatives were identified and confirmed by both ${ }^{31} \mathrm{P}-\mathrm{NMR}$ and MS [7-9,12,18,31].

The molecular weight of GP $\left[\mathrm{C}_{3} \mathrm{H}_{9} \mathrm{O}_{6} \mathrm{P}-\mathrm{H}\right]$ was confirmed at $\mathrm{m} / \mathrm{z} 171$ in the negative ion mode of MS. The other MS peaks confirmed were cyclic-glycerol-monophosphate $\left[\mathrm{C}_{3} \mathrm{H}_{6} \mathrm{O}_{5} \mathrm{P}-\mathrm{H}\right]$ at $\mathrm{m} / \mathrm{z} 152$ and glycerol- diphosphate $\left[\mathrm{C}_{3} \mathrm{H}_{10} \mathrm{O}_{9} \mathrm{P}_{2}-\mathrm{H}\right]$ at $\mathrm{m} / \mathrm{z} 251.0$, respectively. Glycerol-1-phosphate and glycerol-2-phosphate were identified by observing the proton-coupled spectra. The NMR peaks were identified by comparing peak multiplicity 
and shift with both GP standards and with expectations of glycerol-P substances. For example, a triplet results from $\mathrm{CH}_{2}-\mathrm{O}-\mathrm{P}$ on the terminal end of glycerol and a doublet results from a CH-O-P interaction on the second carbon of glycerol [12]. Cyclic GP was identified by a multiplet around $19 \mathrm{ppm}$ and glycerol diphosphates were identified by a triplet and a doublet [31]. Chemical shifts can change as a result of $\mathrm{pH}$ differences caused by various catalysts used in the reactions.

Figures 1-3 show the ${ }^{31} \mathrm{P}-\mathrm{NMR}$ spectra of some of the reactions of glycerol phosphorylation. In the figures, the letters are referenced in Scheme 1. As mentioned above, the glycerol-diphosphates observed were two individual phosphate groups attached to the same glycerol which mainly include: glycerol-1,2-diphosphate and glycerol-1,3-diphosphate. Although, glycerol-1,2,3-triphosphate was also observed, its yield was below $1 \%$.

The other series of reactions studied the decomposition rate of the GP (Figure 5). The decomposition products of GP were phosphate and pyrophosphate. GP degraded into orthophosphate and to pyrophosphate with a half-life of about 7-8 days (Table 2). The unsealed reaction vials heated at $65-70{ }^{\circ} \mathrm{C}$ for 1 week showed the highest decomposition rate, i.e., $46 \%$ lost after 7 days (set 4 ) (Table 2). The decomposition follows a first order rate law for the unsealed experiment (Figure 5). The ${ }^{31} \mathrm{P}-\mathrm{NMR}$ spectra of the phosphorylation reactions of glycerol in the presence of hematite and obsidian (Figures S1 and S2), the ${ }^{31}$ P-NMR spectrum of the standard GP (Figure S3) and the decomposition reactions of GP (Figure S4a-h are given in the Supplementary Materials Section (SM)).

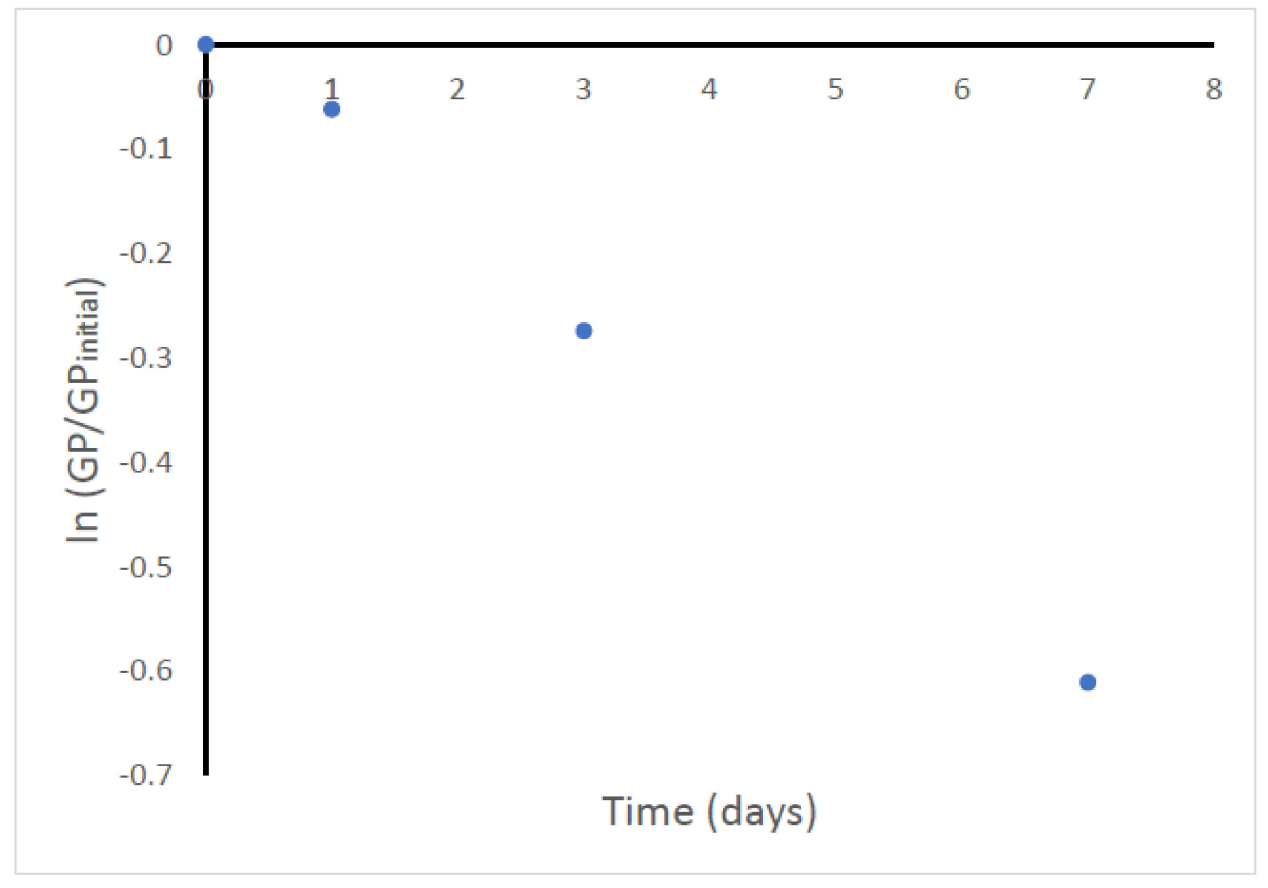

Figure 5. The decomposition rate of GP follows a first order rate law with a hydrolysis half-life of 7.8 days $\left(R^{2}=0.997\right)$.

The phosphate esters of glycerol were successfully synthesized under simplistic conditions and mild heating, conditions that may be considered "prebiotic". In previous studies, GP have been successfully synthesized but in general either yields were low (when water was used as a solvent) $[6,12]$ or the reactions were carried out in non-aqueous solvents such as deep eutectic solvents or formamide [7-9]. This is the first report of diphosphate derivatives of glycerol. The overall yields of the organophosphates ranged from 5-91\%, respectively. The lowest yields were observed only when urea was used as a condensation agent and no catalyst was used. The reactions were also tried at lower temperature windows (i.e., $50^{\circ} \mathrm{C}$ ) but the yields were low compared to the reactions performed at $70{ }^{\circ} \mathrm{C}$ 
even though the same catalysts were used. The overall formation of GP seemed to be much more dependent on temperature and prolonged heating rather than catalysts.

Figure 4 shows the relationship between catalysts and GP forms. In our studies, we found that various catalysts provide certain 'selectivity' towards the formation of various phosphate esters of glycerol. It was observed that the highest yields of monophosphate (GP) were achieved in the presence of kaolinite and ulexite, and the formation of glycerol diphosphate was mostly favored by olivine and hematite (Figure 4). At present, the reason for this selectivity is unknown. However, all minerals and powdered rocks samples favored the formation of GP, as also shown in the previous work that the minerals (regardless of the type) double the yield of the GP [6] with silicates among the best possible catalysts [7]. One possibility is the preferential physical adsorption or chemisorption of the reactants onto various mineral surfaces.

The present work was a mildly hot aqueous reaction conditions mimicking a hot evaporating pool of water or other 'evaporitic environments' as suggested by Cleaves and colleagues [32] in the Hadean. The environment most similar to this work is a mildly hot evaporating pool of water, around $65-70{ }^{\circ} \mathrm{C}$ that has dissolved organics, condensing agents, and salts and minerals. Alternatively, a small hot body of water in volcanic olivine, basalt, or obsidian may also be conducive to GP formation. Urea is widely accepted to be of prebiotic relevance as it has been identified in Miller-Urey's gas discharge tube experiments [33], and it was vital to the condensation reactions reported here.

A warm hot drying pool of water-as also suggested in earlier studies [18] —with dissolved glycerol, an inorganic source of phosphorus (phosphate or reduced phosphorus compounds) [34-36], and minerals could generate cell membrane-forming glycerol phosphates and hence such sites could potentially provide the GP for the emergence of phospholipids for cell membrane formation. The minerals utilized in the present work are also prebiotically relevant $[37,38]$ while oxides of iron, such as hematite and magnetite, are also significant (with hematite being ubiquitous on the surface of Mars [39,40]). Furthermore, serpentinization reactions of olivine- and pyroxene-rich rocks with water produces magnetite [26-29] and would have existed on the Hadean Earth [27,41-44].

The study also shows that phosphorylation is favored at mildly hot temperatures, but prolonged heating can also cause decomposition of the organophosphates [45]. The present study on the rates of decomposition of the GP at mildly high temperatures reveals that GP formation would be balanced by its decomposition. At steady state conditions, the rate of generation of GP $\left(\Phi_{G P}\right)$ would be balanced by its hydrolytic loss ( $\left.k[G P]\right)$ :

$$
\Phi_{G P}=k[G P]
$$

We find a rate of generation of GP to be between 55 and 91\% over the course of three days for mineral-catalyzed reactions. This would correspond to $0.05 \mathrm{M} /$ day as a rate of formation. With a decay constant $k$ of 0.089 (Figure 5), the steady state concentration of GP (as [GP]) would be about $0.5 \mathrm{M}$, assuming no limiting reagents. Such a high steady state concentration implicates this pathway as being prebiotically relevant.

The formation of GP in such a circumstance would be balanced by further modification, either to generate phospholipids or to incorporate GP into protometabolic processes. Each of those would alter the steady state GP concentration. This is consistent with the idea suggested by Clark and Kolb [46] who discussed the possibility of various stages from abiotic synthesis to the possible origin of life to have happened in separate ponds or other sites that might be interconnected, and thus various multi-pot processes could potentially be mixed [47-50]. Hence, the GP produced under hot conditions was transferred to the water bodies with lower temperatures fairly quickly $[46,51-54]$ where it could then become incorporated into other prebiotic processes.

\section{Materials and Methods}

Ammonium dihydrogen phosphate $\left(\mathrm{NH}_{4} \mathrm{H}_{2} \mathrm{PO}_{4}\right)$, urea, ammonium chloride $\left(\mathrm{NH}_{4} \mathrm{Cl}\right)$, sodium carbonate $\left(\mathrm{Na}_{2} \mathrm{CO}_{3}\right)$ sodium chloride $(\mathrm{NaCl})$ and glycerol were purchased from 
Fischer Scientific (Pittsburgh, PA, USA). Deuterium oxide $\left(\mathrm{D}_{2} \mathrm{O}\right)$ and standard glycerol phosphate disodium salt hydrate (isomeric mixture) were obtained from Fair Lawn (NJ, USA). All chemicals utilized in the study were used as received. The deionized (DI) water was obtained by using a Barnstead (Dubuque, IA, USA) NANO pure®Diamond Analytical combined reverse osmosis-deionization system [18].

Ulexite $\left(\mathrm{NaCaB}_{5} \mathrm{O}_{9} \cdot 8 \mathrm{H}_{2} \mathrm{O}\right)$ was purchased from eBay and was crushed to fine powder (30-40 $\mu \mathrm{m}$ grain size) before further proceeding. Kaolinite $\left(\left(\mathrm{Al}_{2} \mathrm{Si}_{2} \mathrm{O}_{5}(\mathrm{OH})_{4}\right) 25-35 \mu \mathrm{m}\right.$ grain size) and white quartz $\left(\mathrm{SiO}_{2}\right)$ as sand $(200-800 \mu \mathrm{m}$ grain size) were purchased from MP Biomedicals (Santa Ana, CA, USA). Magnetite $\left(\mathrm{Fe}_{3} \mathrm{O}_{4}\right)$ and hematite $\left(\mathrm{Fe}_{2} \mathrm{O}_{3}\right)$ (both having a grain size around $100-800 \mu \mathrm{m}$ ) were purchased from Fisher Scientific. Antigorite (a serpentinite mineral, $\left.\mathrm{Mg}, \mathrm{Fe}^{2+}\right)_{3} \mathrm{Si}_{2} \mathrm{O}_{5}(\mathrm{OH})$ was collected from Klamath mountain, OR (USA), while forsterite $\left(\mathrm{Mg}_{2} \mathrm{SiO}_{4}\right)$ (olivine) sample was obtained from Jackson, NC (USA). Basalt sample was collected from the Hawaiian Islands, HI, (USA) while obsidian was from Newberry crater, OR (USA).

\subsection{Phosphorylation of Glycerol}

In a typical reaction, $0.15 \mathrm{~g}(1.3 \mathrm{mmoles})$ ammonium dihydrogen phosphate $\mathrm{NH}_{4} \mathrm{H}_{2} \mathrm{PO}_{4}, 0.2 \mathrm{~g}$ (3.3 mmoles) urea (used as a condensation agent), $1.2 \mathrm{~g}$ (13 mmoles) glycerol were added to a clean glass vial $(15 \mathrm{~mL}$ capacity) with $5 \mathrm{~mL}$ DI water. The mixture was stirred at room temperature until a clear solution was formed. To this solution $0.5 \mathrm{~g}$ of rock, mineral, or salt was added. Each catalyst was tried in a separate reaction (e.g., one at a time). The initial $\mathrm{pH}$ of the reaction was $8-8.5$. The reaction mixture was then heated at $65-70{ }^{\circ} \mathrm{C}$ for 3 days. The reaction vials were kept unsealed to allow for the evaporation of water under heating and to mimic a hot drying pool of water containing the reactants as reported previously [18].

\subsection{Decomposition Reaction Studies of the Glycerol Phosphates}

The decomposition reactions of GP were performed to quantitatively as well as qualitatively observe their decomposed products. To study the decomposition reactions of GP, $0.21 \mathrm{~g}$ of standard GP was added to $10 \mathrm{~mL}$ of DI water and was analyzed at 1 day (set 2), 3 days (set 3 ), and 7 days (set 4 ), $65-70{ }^{\circ} \mathrm{C}$ open (or unsealed conditions, exactly like the synthesis of GP mentioned in Section 3.1) and $65-70{ }^{\circ} \mathrm{C}$ closed (the reactions vials were tightly sealed) at 1 day (set 6), 3 days (set 7), and 7 days (set 8), respectively. Both unsealed (set 1 ) and sealed reactions (set 5) were also observed at room temperature for about 7 days.

\section{3. ${ }^{31}$ P-NMR and Mass Spectrometry Analyses of GP Reactions}

The ${ }^{31} \mathrm{P}-\mathrm{NMR}$ studies were performed on unity INOVA spectrometer. The instrumental details and all the optimized conditions of the analyses have been discussed in our previous studies $[7-9,12,18]$.

The reaction samples as a consequence of continuous heating were dried to completion under room temperature with the exception of unreacted liquid glycerol left in each sample (if any). If the reaction sample had minerals/rock samples such as magnetite, hematite, basalt, obsidian, serpentinite, olivine, it was rehydrated with about $3 \mathrm{~mL}$ of $1 \mathrm{M} \mathrm{NaOH}$ solution to precipitate out iron as water insoluble iron hydroxide. This was done for the better analysis of NMR spectra which would be negatively impacted by the presence of $\mathrm{Fe}^{2+}$ ions in solution. The reaction samples were then centrifuged, and the clear supernatant was transferred to a watch glass and let dry at room temperature. The dried samples in the watch glass were rehydrated with $\mathrm{D}_{2} \mathrm{O}$ and their ${ }^{31} \mathrm{P}-\mathrm{NMR}$ studies were performed. The signal was averaged from 3000 transients.

For the confirmation and matching of the target products (glycerol-1-phosphate and glycerol-2-phosphate), the reaction samples were spiked with the standard GP. Spiking was performed by transferring equal volumes of the reaction solutions in two clean NMR tubes. One NMR tube was labeled as A while the other was labeled as B. The ${ }^{31} \mathrm{P}-\mathrm{NMR}$ spectrum of the tube A was recorded. To the NMR tube B, around $0.018 \mathrm{~g}$ (solid) standard GP 
(isomeric mixture) was slowly added. Tube B was shaken gently until the added standard GP was completely dissolved. The ${ }^{31} \mathrm{P}-\mathrm{NMR}$ of the tube B "spiked" with the standard was also recorded. The ${ }^{31} \mathrm{P}-\mathrm{NMR}$ spectra of the tubes $\mathrm{A}$ and $\mathrm{B}$ were compared and studied. The results showed that the peaks of glycerol-1-phosphate and glycerol-2-phosphates exactly matched with that of the peaks in the reaction samples (Figure 3). This step confirmed the formation of the target GP.

Mass spectrometry (MS) analyses (negative ion mode) were performed on a 6130 Single Quadrupole Mass Spectrometer (Agilent, Santa Clara, CA, USA) attached to an Agilent 1200 HPLC by direct injection, and DI water was used as a solvent [18].

Supplementary Materials: The following are available online at https: / www.mdpi.com/article / 10.3390/catal11111384/s1, Figure S1: ${ }^{31}$ P-NMR figure of GP formation in the presence of hematite, Figure S2: ${ }^{31} \mathrm{P}-\mathrm{NMR}$ of GP formation in the presence of obsidian, Figure S3: ${ }^{31} \mathrm{P}-\mathrm{NMR}$ of the standard glycerol phosphate, Figure S4a-h: ${ }^{31} \mathrm{P}-\mathrm{NMR}$ of the decomposition reactions of the GP

Author Contributions: M.G. designed the conceptualization and main idea, conducted research, and wrote the research article. M.A.P. designed the experiments and wrote the paper. All authors have read and agreed to the published version of the manuscript.

Funding: This work was supported by NASA Exobiology program (80NSSCC18K1288).

Data Availability Statement: Not applicable.

Acknowledgments: This work has been supported in part by University of South Florida Interdisciplinary NMR Facility, The Department of Chemistry and the College of Arts and Sciences, Tampa, Florida. The mass spectrometry data analysis has been supported by the Chemical Purification Analysis and Screening Core Facility (CPAS) at University of South Florida. Authors thank Katrinah Tirado and Kyle Pedretty at the USF-NMR facility for the help with NMR and Laurent Calcul for mass spectrometric analysis. Maheen Gull is extremely thankful to Ryan Barkley for the help with the editing and formatting of the manuscript preparation and her daughters Luna and Nova Barkley for inspiration and motivation.

Conflicts of Interest: The authors declare no conflict of interest.

\section{References}

1. Pasek, M.A.; Kee, T.P. On the origin of phosphorylated biomolecules. In Origins of Life: The Primal Self-Organization; Egel, R., Lankenau, D.-H., Mulkidjanian, A.Y., Eds.; Springer: Berlin/Heidelberg, Germany, 2011; pp. 57-84.

2. Lombard, J.; Lopez-Garcia, P.; Moreira, D. The early evolution of lipid membranes and the three domains of life. Nat. Rev. Genet. 2012, 10, 507-515. [CrossRef]

3. Peretó, J.; Lopez-Garcia, P.; Moreira, D. Ancestral lipid biosynthesis and early membrane evolution. Trends Biochem. Sci. 2004, 29, 469-477. [CrossRef]

4. Gull, M.; Pasek, M.A. The Role of Glycerol and Its Derivatives in the Biochemistry of Living Organisms, and Their Prebiotic Origin and Significance in the Evolution of Life. Catalysts 2021, 11, 86. [CrossRef]

5. $\quad$ Epps, D.E.; Nooner, D.W.; Eichberg, J.; Sherwood, E.; Oró, J. Cyanamide mediated synthesis under plausible primitive earth conditions. VI. The synthesis of glycerol and glycerophos-phates. J. Mol. Evol. 1979, 14, 235-241. [CrossRef] [PubMed]

6. Gull, M.; Ge, T.; Yingwu, W.; Chao, H.; Zhan, S.; Hongming, Y.; Shouhua, F. Resolving the enigma of prebiotic C-O-P bond formation: Prebiotic hydrothermal synthesis of important biological phosphate esters. Heteroat. Chem. 2010, 21, 161-167.

7. Gull, M.; Cafferty, B.J.; Hud, N.V.; Pasek, M.A. Silicate-Promoted Phosphorylation of Glycerol in Non-Aqueous Solvents: A Prebiotically Plausible Route to Organophosphates. Life 2017, 7, 29. [CrossRef]

8. Gull, M.; Zhou, M.; Fernández, F.M.; Pasek, M.A. Prebiotic Phosphate Ester Syntheses in a Deep Eutectic Solvent. J. Mol. Evol. 2013, 78, 109-117. [CrossRef]

9. Burcar, B.; Pasek, M.; Gull, M.; Cafferty, B.J.; Velasco, F.; Hud, N.V.; Menor-Salván, C. Darwin's Warm Little Pond: A One-Pot Reaction for Prebiotic Phosphorylation and the Mobilization of Phosphate from Minerals in a Urea-Based Solvent. Angezw. Chem. Int. Ed. 2016, 55, 13249-13253. [CrossRef]

10. Gibard, C.; Bhowmik, S.; Karki, M.; Kim, E.-K.; Krishnamurthy, R. Phosphorylation, oligomerization and self-assembly in water under potential prebiotic conditions. Nat. Chem. 2017, 10, 212-217. [CrossRef]

11. Maguire, O.R.; Smokers, I.; Huck, W.T. A physicochemical orthophosphate cycle via a kinetically stable thermodynamically activated intermediate enables mild prebiotic phosphorylations. Nat. Commun. 2021, 12, 15517.

12. Pasek, M.A.; Harnmeijer, J.P.; Buick, R.; Gull, M.; Atlas, Z. Evidence for reactive reduced phosphorus species in the early Archean ocean. Proc. Natl. Acad. Sci. USA 2013, 110, 10089-10094. [CrossRef] [PubMed] 
13. Zhu, C.; Turner, A.M.; Abplanalp, M.J.; Kaiser, R.I.; Webb, B.; Siuzdak, G.; Fortenberry, R.C. An interstellar synthesis of glycerol phosphates. Astrophys. J. Lett. 2020, 899, L3. [CrossRef]

14. Lago, J.L.; Burcar, B.T.; Hud, N.V.; Febrian, R.; Mehta, C.; Bracher, P.J.; Atlas, Z.D.; Pasek, M.A. The Prebiotic Provenance of Semi-Aqueous Solvents. Orig. Life Evol. Biosph. 2020, 50, 1-14. [CrossRef] [PubMed]

15. Schwartz, A.W. Phosphorus in prebiotic chemistry-an update and a note on plausibility. In Handbook of Astrobiology; Kolb, V., Ed.; CRC Press: Boca Raton, FL, USA, 2019; pp. 355-359.

16. Österberg, R.; Orgel, L.E.; Lohrmann, R. Further studies of urea-catalyzed phosphorylation reactions. J. Mol. Evol. 1973, 2, 231-234. [CrossRef]

17. Fiore, M.; Strazewski, P. Prebiotic Lipidic Amphiphiles and Condensing Agents on the Early Earth. Life 2016, 6, 17. [CrossRef] [PubMed]

18. Gull, M.; Omran, A.; Feng, T.; Pasek, M.A. Silicate-, magnesium ion-, and urea-induced prebiotic phosphorylation of uridine via pyrophosphate; revisiting the hot drying water pool scenario. Life 2020, 10, 122. [CrossRef] [PubMed]

19. Gull, M. Prebiotic Phosphorylation Reactions on the Early Earth. Challenges 2014, 5, 193-212. [CrossRef]

20. Furukawa, Y.; Horiuchi, M.; Kakegawa, T. Selective Stabilization of Ribose by Borate. Orig. Life Evol. Biosph. 2013, 43, 353-361. [CrossRef] [PubMed]

21. Franco, A.; Silva, J.A.L. Boron in Prebiological Evolution. Angew. Chem. Int. Ed. 2020, 60, 10458-10468. [CrossRef]

22. Scorei, R. Is Boron a Prebiotic Element? A Mini-review of the Essentiality of Boron for the Appearance of Life on Earth. Orig. Life Evol. Biosph. 2012, 42, 3-17. [CrossRef] [PubMed]

23. Grew, E.S.; Bada, J.L.; Hazen, R.M. Borate Minerals and Origin of the RNA World. Orig. Life Evol. Biosph. 2011, 41, 307-316. [CrossRef]

24. Schwartz, A.W. Phosphorus in prebiotic chemistry. Philos. Trans. R. Soc. B Biol. Sci. 2006, 361, 1743-1749. [CrossRef]

25. Tollari, N.; Toplis, M.; Barnes, S.-J. Predicting phosphate saturation in silicate magmas: An experimental study of the effects of melt composition and temperature. Geochim. Cosmochim. Acta 2006, 70, 1518-1536. [CrossRef]

26. Walton, C.R.; Shorttle, O.; Jenner, F.E.; Williams, H.M.; Golden, J.; Morrison, S.M.; Downs, R.T.; Zerkle, A.; Hazen, R.M.; Pasek, M. Phosphorus mineral evolution and prebiotic chemistry: From minerals to microbes. Earth-Sci. Rev. 2021, 221, 103806. [CrossRef]

27. Guo, F.-F.; Svetov, S.; Maier, W.D.; Hanski, E.; Yang, S.-H.; Rybnikova, Z. Geochemistry of komatiites and basalts in Archean greenstone belts of Russian Karelia with emphasis on platinum-group elements. Miner. Deposita 2019, 55, 971-990. [CrossRef]

28. Schulte, M.; Blake, D.; Hoehler, T.; McCollom, T. Serpentinization and Its Implications for Life on the Early Earth and Mars. Astrobiology 2006, 6, 364-376. [CrossRef] [PubMed]

29. Pasek, M.; Omran, A.; Lang, C.; Gull, M.; Abbatiello, J.; Feng, T.; Garong, L.; Abbott-Lyon, H. Serpentinization as a Route to Liberating Phosphorus on Habitable Worlds. Res. Sq. 2020. [CrossRef]

30. Barnes, S.; Arndt, N.T. Distribution and Geochemistry of Komatiites and Basalts Through the Archean. In Earth's Oldest Rocks; Elsevier: Amsterdam, The Netherlands, 2018; pp. 103-132. [CrossRef]

31. Barber, D.J.; Scott, E. Origin of supposedly biogenic magnetite in the Martian meteorite Allan Hills 84001. Proc. Natl. Acad. Sci. USA 2002, 99, 6556-6561. [CrossRef] [PubMed]

32. Pasek, M.A. Phosphorus NMR of Natural Samples; Amazon: Seattle, WA, USA, 2018.

33. Cleaves, H.J., II; Scott, A.M.; Hill, F.C.; Leszczynski, J.; Sahai, N.; Hazen, R. Mineral-organic interfacial processes: Potential roles in the origins of life. Chem. Soc. Rev. 2012, 41, 5502-5525. [CrossRef] [PubMed]

34. Miller, S.L. Production of Some Organic Compounds under Possible Primitive Earth Conditions1. J. Am. Chem. Soc. 1955, 77, 2351-2361. [CrossRef]

35. Pasek, M.; Dworkin, J.; Lauretta, D. A radical pathway for phosphorylation during schreibersite corrosion with implications for the origin of life. Geochim. Cosmochim. Acta 2007, 71, 1721-1736. [CrossRef]

36. Pasek, M.A.; Kee, T.P.; Bryant, D.E.; Pavlov, A.A.; Lunine, J.I. Production of potentially prebiotic condensed phosphates by phosphorus redox chemistry. Angew. Chem. Int. Ed. Engl. 2008, 47, 7918-7920. [CrossRef] [PubMed]

37. Yamagata, Y.; Watanabe, H.; Saitoh, M.; Namba, T. Volcanic production of polyphosphate under primitive Earth conditions. Nature 1991, 204, 516-519. [CrossRef] [PubMed]

38. Hazen, R.M.; Sverjensky, D.A. Mineral Surfaces, Geochemical Complexities, and the Origins of Life. Cold Spring Harb. Perspect. Biol. 2010, 2, a002162. [CrossRef]

39. Lambert, J.B.; Gurusamy-Thangavelu, S.A.; Ma, K. The silicate-mediated formose reaction: Bottom-up synthesis of sugar silicates Science 2010, 327, 984-986. [CrossRef]

40. Allen, C.C.; Westall, F.; Schelble, R.T. Importance of a Martian Hematite Site for Astrobiology. Astrobiology 2001, 1, 111-123. [CrossRef]

41. Williams, A.J.; Sumner, D.Y.; Alpers, C.N.; Karunatillake, S.; Hofmann, B.A. Preserved Filamentous Microbial Biosig-natures in the Brick Flat Gossan, Iron Mountain, California. Astrobiology 2015, 15, 637-668. [CrossRef]

42. Russell, M.J.; Ponce, A. Six 'Must-Have' Minerals for Life's Emergence: Olivine, Pyrrhotite, Bridgmanite, Serpentine, Fougerite and Mackinawite. Life 2020, 10, 291. [CrossRef] [PubMed]

43. Santosh, M.; Arai, T.; Maruyama, S. Hadean Earth and primordial continents: The cradle of prebiotic life. Geosci. Front. 2016, 8 , 309-327. [CrossRef] 
44. Sleep, N.H.; Bird, D.K.; Pope, E.C. Serpentinite and the dawn of life. Philos. Trans. R. Soc. B Biol. Sci. 2011, 366, $2857-2869$. [CrossRef]

45. Larralde, R.; Robertson, M.P.; Miller, S.L. Rates of decomposition of ribose and other sugars: Implications for chemical evolution. Proc. Natl. Acad. Sci. USA 1995, 92, 8158. [CrossRef] [PubMed]

46. Clark, B.C.; Kolb, V.M. Macrobiont: Cradle for the Origin of Life and Creation of a Biosphere. Life 2020, 10, 278. [CrossRef] [PubMed]

47. Damer, B.; Deamer, D. The Hot Spring Hypothesis for an Origin of Life. Astrobiology 2020, 20, 429-452. [CrossRef] [PubMed]

48. Deamer, D.W. Assembling Life: How Can Life Begin on Earth and Other Habitable Planets? Oxford University Press: Oxford, UK, 2018.

49. Sutherland, J.D. The Origin of Life-Out of the Blue. Angew. Chem. Int. Ed. 2015, 55, 104-121. [CrossRef] [PubMed]

50. Ritson, D.J.; Battilocchio, C.; Ley, S.V.; Sutherland, J.D. Mimicking the surface and prebiotic chemistry of early Earth using flow chemistry. Nat. Commun. 2018, 9, 1821. [CrossRef]

51. Ferris, J.P.; Hill, A.R.; Liu, R.; Orgel, L.E. Synthesis of long prebiotic oligomers on mineral surfaces. Nature 1996, $381,59-61$. [CrossRef] [PubMed]

52. Huang, W.; Ferris, J.P. One-step, regioselective synthesis of up to 50-mers of RNA oligomers by montmorillonite catalysis. J. Am. Chem. Soc. 2006, 128, 8914-8919. [CrossRef]

53. Pedreira-Segade, U.; Hao, J.; Razafitianamaharavo, A.; Pelletier, M.; Marry, V.; Le Crom, S.; Michot, L.J.; Daniel, I. How do Nucleotides Adsorb Onto Clays? Life 2018, 8, 59. [CrossRef]

54. Hashizume, H. Adsorption of Nucleic Acid Bases, Ribose, and Phosphate by Some Clay Minerals. Life 2015, 5, 637-650. [CrossRef] 